\title{
Phylogeny and biogeography of southern African spoon-winged lacewings (Neuroptera: Nemopteridae: Nemopterinae)
}

\author{
Catherine L. Sole ${ }^{\mathrm{a}}$, Clarke H. Scholtz ${ }^{\mathrm{a}}$, Jonathan B. Ball ${ }^{\mathrm{a}}$ and Mervyn W. Mansell ${ }^{\mathrm{a}}$
}

${ }^{\text {a }}$ Department of Zoology and Entomology, University of Pretoria, Private Bag X20, Hatfield, 0028, Pretoria, South Africa

Corresponding author: Catherine L. Sole

Email: clsole@,zoology.up.ac.za

Telephone number: +27124203236

Fax: +27 123625242

Postal address: Department of Zoology and Entomology, University of Pretoria, Private Bag X20, Hatfield, 0028, Pretoria, South Africa

\begin{abstract}
Nemopteridae are a charismatic family of lacewings characterised by uniquely extended hind wings. They are an ancient widespread group in the drier regions of the world. The family comprises two subfamilies, Crocinae (thread-wings) and Nemopterinae (spoon- and ribbon-wings). The present distribution of the family has been largely influenced by the vicariant events of plate tectonics, resulting in relict populations in some parts of the world and extensive evolutionary radiations in others, particularly southern Africa where the vast majority of the species are endemic to the Western and Northern Cape Provinces of South Africa. This study aimed to establish the validity of the 11 currently recognised genera and infer their biogeographic history using molecular sequence data from four gene regions. The hypothesis that the Cape nemopterines co-evolved with certain taxa in the Cape Floristic Region was also tested.

Phylogenetic analysis supports seven of the 11 currently recognised genera. The crown age of the Nemopterinae is estimated to be at $c a .145 .6 \mathrm{Mya}$, indicating that the group has been present since the late Jurassic. Most of the genera appear to have diversified during the middle Eocene and into the middle Miocene (ca. 44 - 11 Mya) with recent rapid radiation of several of the genera occurring during the late Miocene (ca. 6 - 4.5 Mya). While these data support an initial radiation with the Rushioideae (Aizoaceae) it is recommended that further study including observations and gut content be carried out. [238]
\end{abstract}

\section{Keywords}

Nemopteridae, Nemopterinae, Lacwings, Phylogeny, Biogeography, Cape Floristic Region 


\section{Introduction}

Nemopteridae are a charismatic family of lacewings characterised by uniquely extended hind wings. They are the only entire insect family with this innovation that has further evolved into a range of striking forms with specialised functions that include aerodynamics, camouflage, mate recognition and tactile responses (Mansell, 1996). The family comprises two subfamilies, Crocinae (thread-wings) and Nemopterinae (spoon- and ribbon-wings). Crocinae have filamentous hind wings that have a sensory function in the confined cavernicolous habitats they occupy (Mansell, 1996), while those of Nemopterinae vary from ribbon-shaped to extensive dilations that are pigmented and aerodynamically twisted to provide stability during flight as well as camouflage when at rest (Mansell, 1996). In some diurnal South African taxa additional functions of the hind wings include heat absorption when sitting on a substrate and semiotic functioning when the black and white bilobed hind wings of Sicyoptera Navás species are rapidly ratcheted dorsally and ventrally (Ball pers. obs.). Although these functions have been refuted (Leon and Picker, 1990b; Picker, 1984) for the species Palmipenna aeoleoptera Picker, numerous field observations (Ball, Brinkman and Mansell, pers. obs) on other taxa: Sicyoptera, Barbibucca Tjeder and Palmipenna pilicornis Tjeder (1967) provide strong support for these functions. The ephemeral adults usually have elongated mouthparts that have evolved in response to their specialist pollenophagous diet. Larvae by contrast, are all predacious with the autapomorphy of piercing and sucking mouthparts that defines the order Neuroptera. Larval nemopterids occupy a variety of habitats ranging from small caves and rock overhangs, disused buildings and hollow tree trunks, to psammophiles and litter-dwellers, to inquilines in the nests of ants. The first crocine larva, with a bizarrely elongated prothorax, was discovered in tombs at the pyramids of Giza in Egypt (Roux, 1833), giving rise to the almostmythological status of Nemopteridae.

Nemopterids are an ancient group of lacewings that are widespread in the drier regions of the world, with the exception of North America where the family is represented only by two fossil records (Carpenter, 1959). Nemopteridae occur in parts of Africa, particularly southern Africa, Socotra Island (1 Nemopterinae, 1 Crocinae), Australia (3 Nemopterinae, 6 Crocinae), South America (1 Nemopterinae, 6 Crocinae), Mediterranean Europe, the Middle East and India (1 Crocinae). The southern African fauna was originally monographed by Tjeder (1967), with several papers dealing with Crocinae (Mansell, 1976, 1977, 1980, 1981a, b, 1986, 1996) and the Nemopterinae (Leon and Picker, 1990a, b; Mansell, 1973; Picker, 1984, 1987; Picker and Leon, 1990; Picker et al., 1991; Picker et al., 1992; Walker et al., 1994) having followed Tjeder's quintessential treatise.

There are currently 142 valid species worldwide, 43 Crocinae and 99 Nemopterinae, and at least a further 10 undescribed nemopterine species in southern Africa. The present distribution of the family appears to have been largely influenced by the vicariance events of plate tectonics, resulting in relic populations in some parts of the world and extensive evolutionary radiations in others, particularly 
southern Africa where 72 species, $48 \%$ of the world's Nemopteridae occur. The vast majority of these, 57 species (38\% of the world fauna) are endemic to the Western and Northern Cape Provinces of South Africa (Figure 1). The southern African Nemopterinae (excluding Crocinae) comprise 57\% (62 species) of the global fauna, with $47 \%$ of the world's taxa (51 species) being endemic to these two provinces of South Africa.

The Cape nemopterines are consequently a unique and rich biological heritage that requires special research and conservation attention. While the subfamily Crocinae is comparatively well known, knowledge of the taxonomy, biology, phylogeny, local biogeography and conservation status of the Nemopterinae remains inadequate beyond that recorded by Tjeder (1967). While the conservation of Crocinae is reasonably assured owing to their arid and rocky habitats, unsuited to agriculture, the Nemopterinae are extremely vulnerable, as many of the habitats of the rare Cape endemics have already been destroyed by agricultural and urban expansion, with the remainder being severely threatened.

The South African Nemopterinae are characterised by numerous fragmented populations, with many species being known from a single locality only, and the almost clockwork precision of adult emergence at specific times of the year and, sometimes only in certain years. This has engendered the notion that they co-evolved with the species-rich Cape flora, leading to the hypothesis that certain plant and nemopterine taxa may be interdependent (Mansell and Ball pers. obs.). Although the Crocinae are central to the evolutionary processes of the family Nemopteridae, there are no observations to indicate that their diversity in southern Africa has been influenced by flowering plant diversity to the same extent as that of the Nemopterinae. The habitats of larval crocines are also different from those of nemopterines, being confined to dusty recesses under rock overhangs, small caves and completely sheltered microhabitats, whereas most nemopterines are not confined by precise habitat requirements, where many species are psammophilous. This unrestricted habitat facilitates mass and synchronised emergence by many nemopterine taxa (Mansell and Ball pers. obs.). The focus of this paper is consequently confined to the subfamily Nemopterinae.

A detailed study of the taxonomy, with emphasis on molecular and morphological analysis, phylogeny, phylogeography, biogeography and biology of the subfamily Nemopterinae is consequently being undertaken. The first priority of these studies, and the main objective of this paper, was to establish the validity of the currently recognised 11 genera using molecular data, as this would provide the basis for investigations into their ecological role and objective criteria for the conservation of a unique South African biological heritage. The overall project is especially designed to validate the hypothesis that the Cape nemopterines co-evolved with certain taxa in the Cape flora, one of the world's six floral kingdoms (Galley and Linder, 2006; Goldblatt and Manning, 2002; Linder, 2003; Linder, 2005; Schulze et al., 2005). By combining the data from four gene regions (16S rDNA, 18S, 28S domain 2 and COI) in a total evidence approach we attempt to resolve the phylogenetic relationships of the 11 currently recognised 
genera. In addition, we estimate divergence times for the origin and diversification of the major lineages within the Nemopterinae.

\section{Material and methods}

\subsection{In-group taxa}

Ten of the eleven genera South African Nemopterinae were included in this phylogenetic study: Barbibucca, Derhynchia Tjeder, Halterina Navás, Knersvlaktia Picker, Nemia Navás, Nemopterella Banks, Nemeura Navás, Palmipenna Tjeder, Semirhynchia Tjeder and Sicyoptera. A single representative of the Australian Nemopterinae, the genus Chasmoptera Westwood, was also included. The only genus not included in this study is Nemopistha Navás, a rare Savanna biome taxon.

\subsection{Out-group taxa}

Considerations for out-group comparisons were based on a recent phylogenetic study of the Neuropterida by Winterton et al. (2010). Based on this a species of Ascalaphidae (Neomelambrotus molestus Tjeder) and a representative of the subfamily Crocinae (Laurhervasia setacea (Klug)) were used as out-group taxa (See Table 1 for details of taxa used in this study).

\subsection{Species identification}

Morphological identifications were provided by a specialist on the group (M.W. Mansell) and based on material in the South African National Collection of Insects, Pretoria and in the J.B. Ball Collection, Cape Town. These two collections are the largest and most comprehensive holdings of southern African Nemopteridae currently available. Molecular analyses were based on freshly-collected specimens, authoritatively identified and further verified by comparison with material in these collections. Fresh material was collected by hand-netting and at mercury vapour light traps and preserved in absolute ethanol.

\subsection{DNA extraction, cycling conditions and sequencing}

Genomic DNA was extracted from a leg of at least three individuals per species representing each genus using the Roche High Pure PCR Template Preparation Kit (Roche, Penzberg, Germany) according to the manufacturer's specifications.

Sequence data were generated for four different gene regions: three ribosomal genes (16S rDNA, 18S rDNA and a portion of the nuclear rRNA large subunit 28S domain 2), along with a single protein coding gene region (cytochrome oxidase I - COI). Primer sequences used to amplify the four gene regions are listed in Table 2. Amplification using polymerase chain reaction (PCR) was performed using the 
following cycling conditions: a C. 456 base pair (bp) fragment of 16S rDNA was generated using the primer pair LR-N-13398 (Simon et al., 1994) and LR-J-12961 (Cognato and Vogler, 2001) and 1221bp of COI using the primer pair C1-J-1718 and TL2-N-3014 (Simon et al., 1994) with the following protocol: initial denaturation at $95^{\circ} \mathrm{C}(5 \mathrm{~min}) ; 33$ cycles of $93^{\circ} \mathrm{C}(20 \mathrm{~s}), 50^{\circ} \mathrm{C}(40 \mathrm{~s}), 72^{\circ} \mathrm{C}(20 \mathrm{~s})$; final extension at $72^{\circ} \mathrm{C}$ (5 min). A C. 836bp of $18 \mathrm{~S}$ rDNA was amplified using the primers $18 \mathrm{~S}-$ intfw-ST12 and 18S-rev1 (Haring and Aspöck, 2004) with the following cycling conditions: initial denaturation at $95^{\circ} \mathrm{C}(2 \mathrm{~min}) ; 30$ cycles of $95^{\circ} \mathrm{C}(10 \mathrm{~s}), 48^{\circ} \mathrm{C}(10 \mathrm{~s}), 72^{\circ} \mathrm{C}(1 \mathrm{~min})$; final extension at $72^{\circ} \mathrm{C}(5 \mathrm{~min})$. A 'three-cycle' touchdown PCR program was used to amplify C. 735bp stretch of $28 \mathrm{~S}$ domain 2: initial denaturation for 20 seconds at $96^{\circ} \mathrm{C}$ was followed by 3 cycles $\left(15 \mathrm{~s}\right.$ at $96^{\circ} \mathrm{C}, 20 \mathrm{~s}$ at $54^{\circ} \mathrm{C}, 1 \mathrm{~min}$ at $\left.72^{\circ} \mathrm{C}\right)$, thereafter 7 cycles $\left(12 \mathrm{~s}\right.$ at $96^{\circ} \mathrm{C}, 18 \mathrm{~s}$ at $53^{\circ} \mathrm{C}, 55$ seconds at $\left.72^{\circ} \mathrm{C}\right)$ and 30 cycles $\left(12 \mathrm{~s}\right.$ at $96^{\circ} \mathrm{C}, 15 \mathrm{~s} 52^{\circ} \mathrm{C}, 50 \mathrm{~s}$ at $72^{\circ} \mathrm{C}$ ) with a final extension of 1 minute at $72^{\circ} \mathrm{C}$. For all gene regions PCR was performed in a final volume of $50 \mu \mathrm{l}$ containing approximately 50 - $100 \mathrm{ng}$ genomic DNA template, $2.5 \mathrm{mM} \mathrm{MgCL} 2,20$ pmol of each primer, $10 \mathrm{~mm}$ dNTP's ( $0.25 \mathrm{mM}$ of each of the four nucleotides (Promega)) and $1 \mathrm{X}$ buffer in the presence of 1 unit of Taq DNA polymerase (Super-Therm ${ }^{\circledR}$ DNA polymerase, Southern Cross Biotechnology)

\subsection{Processing and alignment of sequences}

All sequences were viewed, edited and assembled in CLC Bio 5.6 (http://www.clcbio.com/). Sequences for $16 \mathrm{~S}, 18 \mathrm{~S}$ and $28 \mathrm{~S}$ domain 2 were subsequently aligned using the algorithm described by Löytynoja and Goldman (2005) as implemented in the Probabilistic Alignment Kit (PRANK: http://www.ebi.ac.uk/goldMyan-srv/webPRANK) (Löytynoja and Goldman, 2005, 2008). Once aligned these alignments were checked manually. Alignment results showed areas of these gene regions that are conserved while others have significantly large amounts of inferred indels. Gblocks (Castresana, 2000) was used to select confidently aligned areas by eliminating the poorly aligned positions and divergent regions. The resulting alignment from Gblocks was used in subsequent analyses. The protein-coding gene COI could unambiguously be aligned displaying no stop codons when translated in MacClade version 4.03 (Maddison and Maddison, 1992). Ambiguous sites were coded using the appropriate IUB symbols after double-checking the electropherograms for recognisable sequencing artefacts. All sequences were submitted to GenBank under accession numbers JX294077 - JX294294.

\subsection{Phylogenetic analysis}

Parsimony and Maximum Likelihood analyses were conducted using PAUP* 4.0b10 (Swofford, 2003). We used a heuristic tree search protocol with 10 random addition sequences and tree bisection and reconnection (TBR). For Parsimony we excluded all uninformative characters, gaps were treated as $5^{\text {th }}$ state characters and bootstrap support values (Felsenstein, 1985) were calculated based on 1000 
replicates. Starting trees for the Maximum likelihood (ML) analysis were obtained through the NeighborJoining (NJ) method and bootstrap support values were calculated based on 100 replicates. For ML inference a model for the entire dataset as favoured by the Akaike Information Criteria (AIC) was estimated in MrModelTest version 2.2 (Nylander, 2004). Bayesian analyses were performed in MrBayes version 3.1.2 (Huelsenbeck and Ronquist, 2001). All Bayesian analyses used the model favoured by the AIC implemented in MrModelTest see Table 3 for models of the respective gene regions. All analyses were initiated from random starting trees using one cold and three incrementally heated metropolis coupled chains $(0.01)$ run for 10 million iterations with trees being sampled every $1000^{\text {th }}$ iteration, of which $20 \%$ were discarded during the burn-in, with the posterior probabilities being calculated from the remaining saved majority rule consensus trees. Two independently repeated Monte Carlo Markov Chain (MCMC) approximation runs were performed.

\subsection{Divergence time estimates}

Relaxed molecular clock estimates of divergence time were estimated using Beast version 1.6.2 (Drummond and Rambaut, 2007), a Bayesian coalescent analysis with the MCMC approximation. Nemopterinae were constrained to be monophyletic, reflecting our phylogenetic analysis, and the dataset was partitioned by gene region, with the respective substitution models (Table 3) applied to each partition. The fossil record for the Myrmeleontiforms is relatively diverse with the oldest fossils appearing to represent the stem groups of the Nymphidae, Myrmeleontidae, Ascalaphidae, Psychopsidae and Nemopteridae dating back to the Jurassic (Grimaldi and Engel, 2005). To reflect this a normal prior was applied to the root using the mid-point of the Jurassic (172 million years ago (mya) with a standard deviation of 11) to allow for soft minimum and maximum bounds of 144 and 200 mya, representing the upper and lower bounds of the Jurassic epoch, respectively. Two fossils from the genus Marquettia, morphologically considered the most primitive of the Nemopteridae, were described by Carpenter (1959), from the Eocene-Oligocene boundary (33.9 mya) of the Florissant Shale in Colorado (Grimaldi and Engel, 2005). Based on hind wing shape the fossil genus Marquettia appears morphologically similar to the extant genus Sicyoptera we therefore used the midpoint of 34 million years (my) as a hard minimum age constraint in an exponential prior for the node containing the genera Nemeura, Sicyoptera and Semirhynchia. A soft maximum constraint was applied such that $97.5 \%$ of the prior probability density would fall prior to the 200 mya soft upper bound of the root of the tree. Priors on the ages of unconstrained nodes were derived from a birth-death tree model. Two independent Markov chains were run for 20 million iterations using a random starting tree. The program TRACER version 1.5 (Drummond and Rambaut, 2007) was used to assess the convergence between runs and posterior probabilities of the estimates. 


\section{Results}

\subsection{Dataset properties and phylogeny}

The combined aligned molecular matrix consisted of 2681 base pairs (bp): $16 \mathrm{~S} \approx 434 \mathrm{bp} ; 18 \mathrm{~S} \approx 798 \mathrm{bp}$; domain $2 \approx 663 \mathrm{bp}$ and $\mathrm{COI}=786 \mathrm{bp}$ and included 1053 parsimony informative characters. As with most arthropod genomes the $\mathrm{A} / \mathrm{T}$ bias is reflected here across the four gene regions (Table 3). Parsimony analysis recovered 957 trees with a length of 3431 , CI of 0.505 , RI of 0.853 and RC of 0.430 . A single ML tree was obtained assuming the GTR model with a gamma distribution shape parameter of 0.801 and proportion of invariable sites 0.620. The phylogram depicted in Figure 2 is the Bayesian consensus tree with Bayesian posterior probability, parsimony and ML bootstrap values presented on nodes. Only values above $50 \%$ bootstrap and 0.5 posterior probability are indicated, and nodes with boostrap support values above $70 \%$ and/or posterior probability above 0.95 are considered as strongly supported nodes.

The Nemopterinae were strongly supported as being monophyletic (Bayesian posterior probability (PP) 1.00, Parsimony bootstrap (PB) $98 \%$ and Maximum Likelihood Bootstrap (MLB) $80 \%$ ). Two distinct lineages can be identified within the phylogenetic trees labelled I (1.00 PP; 99 \% PB; 97 \% MLB) and II (0.99 PP; 96 \% PB; 76 \% MLB) (Figure 2), respectively. There are currently 11 recognised genera of Nemopterinae in southern Africa, based on morphological criteria. Within the phylogram seven of the 11 genera are well supported, based on their representative taxa: Barbibucca (1.00 PP; 86 \% PB; $91 \%$ MLB), Derhynchia (1.0 PP; 100 \% PB; 100 \% MLB), Halterina (1.0 PP; 100 \% PB; 100 \% MLB), Knersvlaktia (1.0 PP; 83 \% PB; 99 \% MLB), Nemopterella - excluding Nemopterella africana (1.0 PP; 100 \% PB; 100 \% MLB), Nemia (1.0 PP; 100 \% PB; 100 \% MLB) and Palmipenna (1.0 PP; $100 \%$ PB; $99 \%$ MLB). The genus Palmipenna appears sister to the genera Knersvlaktia, Nemopterella, Barbibuca, Halterina, and Nemia (1.00 PP; 99 \% PB; 97 \% MLB). The genera Barbibucca and Nemia are well supported as sister genera to each other (1.0 PP; $98 \%$ PB; $99 \%$ MLB) and are in turn sister to Nemopterella Africana (1.0 PP; 83 \% PB; 85 \% MLB). A sister relationship between Halterina and Knersvlaktia is only supported by the Bayesian analysis (0.97 PP). Lineage II contains the genera Nemeura, Sicyoptera, Semirhynchia and Chasmoptera. Although this lineage is monophyletic and well supported the genera Nemeura, Sicyoptera and Semirhynchia are polyphyletic. Derhynchia forms a wellsupported genus sister to all the genera in lineage II, including the Australian genus Chasmoptera.

\subsection{Divergence estimates}

The blue bars in Figure 3 indicate the $95 \%$ high posterior density (HPD) interval for each divergence. The mean estimated divergence of the Nemopterinae (including Chasmoptera) is ca. 145.61 million years ago (mya), late Jurassic. The split between lineages I and II (as depicted in Figure 2) appears to have occurred during the mid Cretaceous ( $c a .119 .71$ mya). The divergence of the southern African Nemopterinae appears to have occurred gradually with two distinct patterns being obvious. Most of the 
genera appear to have diversified gradually during the middle Eocene ( $c a .44$ mya) to the middle Miocene (ca. 11 mya) while other genera have diverged more recently during the last $c a .4 .5$ million years (Figure $3)$.

\section{Discussion}

This study is the most comprehensive phylogenetic analysis yet undertaken on Nemopterinae. The overall phylogeny appeared well resolved, the Nemopterinae are monophyletic and a good indication is given as to which genera are well supported.

\subsection{Phylogenetic considerations}

Two major lineages are revealed by the molecular analysis, the first comprising the genera Nemia, Barbibucca, Halterina, Nemopterella, Knersvlaktia and Palmipenna (lineage I - Figure 2). The second lineage consisting of Nemeura, Sicyoptera, Semirhynchia, and including the exotic Chasmoptera shows two clear separations (Gen. \& sp. nov, Semirhynchia sp. nov. and Chasmoptera) and a polyphyletic complex of Nemeura, Sicyoptera cuspidata and Semirhynchia sp. nov., which requires further investigation. The genera in lineages I and II are also distinguished morphologically in that the former have abdomens that are short and stout, whereas the latter have long and slender abdomens. Pleuritocavae occur sporadically in the male abdomen among the genera of lineage I, but are absent from all members of lineage II. Nocturnally active species are divided between the two lineages, Nemopterella and Nemia (lineage I) and Semirhynchia and Nemeura (lineage II). The remaining genera are diurnal a potential further adaptation to their pollenophagous habits.

The close morphological similarity between Nemia and Nemopterella is not supported by molecular data in the phylogeny (Figure 2). This raises the question of reliable morphological characters to distinguish these two genera. Most Nemopterella species, which are morphologically difficult to separate from one another, are superficially distinct from Nemia, although these morphological distinctions are tenuous - requiring further study. Navás (1915) divided the genus Nemopterella into two, Nemeva, with type species Nemopteryx africana Leach, 1815 and Nemia, with type species Nemoptera costalis Westwood, 1836. According to Tjeder (1967) this separation was based on inconsistent characters of no taxonomic significance, but he did discover an important feature, the presence of pleuritocavae in the male of $N$. africana that were absent from that of $N$. costalis, and he separated the two genera on that clear basis. Tjeder (1967) then synonymised Nemeva Navás with Nemopterella, as a valid existing name (Nemopterella) cannot be substituted by a new name with the same type species. However, further species recently discovered in South Africa that could be assigned to Nemia have pleuritocavae thereby casting doubt upon their value in distinguishing Nemia and Nemopterella. Nemopterella africana is indicated as distinct from both Nemia and Nemopterella although it shares the important distinguishing features of both genera (pleuritocavae as in Nemopterella and the characteristic body patterns of Nemia). 
It consequently suggests that $N$. africana may represent a previously undetected monotypic genus and also that the main distinguishing feature currently separating Nemia and Nemopterella (pleuritocavae) may not be supported by molecular data.

The genus Barbibucca is morphologically distinctive in that they are robust with uniformly broad hind wings. The genus Knersvlaktia has been distinguished from other genera, and is clearly underpinned by molecular data.The morphologically distinctive diurnal genus Palmipenna has several distinguishing characters: antennae short and stout less than half forewing length, hind wings less than twice forewing length with broad apical dilations and very small eyes characteristic of diurnal taxa. Molecular data unequivocally support Palmipenna as a valid genus. The genus Halterina is also morphologically distinct, and its two species are supported by molecular data.

Derhynchia is a distinct monotypic genus supported by the autapomorphy of reduced mouthparts and rostrum, the only nemopterine with this unique feature. The biology of this genus is also unique in that it inhabits the dunes in the Kalahari ecosystem where its free-living psammophilous larva lives several centimetres under the sand surface near vegetation. The larva also has several unique features including vestigial eyes and peculiar burrowing behaviour, indicating that the entire larval life is spent underground (Mansell, 1973). The most readily available food source for adults is pollen from dune grasses that do not require a long rostrum for harvesting, probably leading to the secondarily atrophied mouthparts.

In lineage II, Nemeura, Semirhynchia and Sicyoptera are morphologically distinct from one another. Semirhynchia has distinctive short mouthparts and ribbon-shaped wings, while Sicyoptera is easily distinguished from Nemeura by the broad double pre-apical expansions of the hind wings. The value of the hind wing shape in distinguishing genera is however, questionable as broad hind wings occur over a wide range of taxa, especially those in this study (lineages I and II). Furthermore, a newly discovered taxon (Gen. \& sp. nov.) which also has broad double pre-apical hind wing expansion, and closely resembles species of Sicyoptera, separates out from other genera within this group, and is furthermore distinguished by forewing characteristics supporting its molecular distinction

The molecular analysis applied in this study has led to three important conclusions. It has shown clear support for at least seven of the southern African genera currently based on morphological criteria, it has indicated that further studies, both morphological and molecular are required on the remaining three genera, and it has also indicated the correct generic placement for taxa that were previously doubtful. It has furthermore, revealed two distinct major lineages, with lineage II apparently more closely related to the Australian Chasmoptera, possibly suggesting that it may comprise an ancestral lineage of the Nemopterinae. The family is clearly a Gondwanan element with the sporadic relic distribution on the southern continents being due to plate tectonics. Only one species, Stenorrhachus walkeri (McLachlan) remains in South America, while one genus, Chasmoptera with three described species $(C$. hutti (Westwood), C. mathewsi Koch and C. superba Tillyard all confined to Western Australia near Perth, is the only representative of the Nemopterinae in the Australasian region. The fact that genera in lineage II 
are most closely related to Chasmoptera suggests that they are part of the lineage that emerged before South America and Australia became separated, and before the major radiation took place on the southern African fragment. Chasmoptera is also morphologically very similar to Sicyoptera, and to the two fossil Nemopterinae, Marquettia americana (Cockerell) and M. metzeli (Pierce and Kirkby), from North America, as well as to some species of the Palaearctic genus, Lertha Navás, suggesting that the double pre-apical dilation of the hind wing may be part of the "groundplan" of the Nemopterinae that has been retained by widely disparate genera, including the enigmatic Parasicyoptera guichardi Tjeder, known only from Socotra Island.

\subsection{Biogeographic inferences and speciation events}

The Cape Floristic Region (CFR), one of six floral kingdoms (Galley and Linder, 2006; Goldblatt and Manning, 2002; Linder, 2003; Linder, 2005; Schulze et al., 2005) and its extent encompasses the bulk of the distribution of the South African nemopterines (Figure 1). The biomes in which South African Nemopterinae occur are Fynbos, Succulent Karoo, Nama Karoo, Albany Thicket and Savanna biomes (Mucina and Rutherford, 2006). Recent detailed paleoclimatic records indicate that large fluctuations in the African climate have caused changes, among others, in the topology, ecology and soil which, in turn, has had a major effect on the speciation, extinction and dispersal of the flora and fauna over the last 5 - 6 mya (deMenocal, 2004). These landscape type changes result in the island-like fragmentation of a habitat, which in turn may act as speciation 'hotspots' (Linder, 2003). One of the major driving forces behind the floral diversification within CFR is thought to be the Plio-Pleistocene glacial and interglacial cycles and the onset of the winter rainfall regime, having occurred ca. 5 mya (deMenocal, 1995; deMenocal, 2004; Linder, 2003) with African bovids, birds and hominids having diversified over the last ca. 2 - 3 mya (deMenocal, 2004; Linder, 2003; Potts, 1998). In particular, the increase in aridity that is accentuated by the rain shadow created by the Great Escarpment and reinforced by the cold upwelling of the Benguela current system and the subtropical anticyclone (Late Miocene) is thought to have played a major role in the CFR diversification (deMenocal, 2004; Linder, 2003; van Zinderen Bakker, 1975; Ward et al., 1983). It has been suggested that allopatric faunal distribution may have therefore been driven by distributional changes and fragmentation of the flora as a result of climatic oscillations (Price et al., 2007; Tolley et al., 2006).

The flora of the CFR sensu lato can be divided into three elements: (1) a Succulent Karoo element that has its main diversity in the northern part of the CFR e.g. Mesembryanthemum sensu stricto (2) a Tropical African element in which the main diversity occurs to the east of the CFR e.g. Rhus, Aloe and many genera typical of ticket and forest vegetation and, (3) the so-called 'Cape clades' occurring in the South Western Region (Bolus, 1886) that all have their species richness centred within the CFR e.g. Erica, Proteaceae, Bruniaceae, Restionaceae p.p, and Phylica. 
It is hypothesised here that the Nemopterinae have co-evolved mainly with Ruschioideae (Aizoaceae). The Aizoaceae have their greatest diversity in the summer-dry west and reach into Namaqualand up to the Orange River (Linder, 2003). The sub-family Ruschioideae contains approximately1600 species almost exclusively endemic to southern Africa, are the most speciose sub-family within the Aizoaceae and dominate the Namaqualand in terms of species numbers and density. The core Ruschiodeae radiation driven by the onset of the winter rainfall regime was estimated to have occurred c. 3.8 - 7.8 Ma (Klak et al., 2004).

Two hypotheses exist regarding the high species diversity of the CFR, either the flora and fauna of the CFR have undergone rapid diversification or there has been a slow accumulation of species over time (Galley et al., 2007; Linder, 2003). When looking more closely at the climatic changes since the early Oligocene, the west appears to have undergone a gradual change in climate (Linder, 2005), arid to semiarid conditions interspersed with wetter periods (Klak et al., 2004), indicating that the two hypotheses are not necessarily mutually exclusive. A wide range of postulated dates exists for the radiation of the Cape Flora, those dating back to the arid phase in the early Oligocene indicate a slow accumulation of diversity, while others show typical recent rapid radiations (Linder, 2005). The crown age of the Nemopterinae is estimated to be at $c a .119 .7$ mya (144.8 - 97.2; upper and lower estimates, respectively), indicating that the group has been present since the Cretaceous. Most of the genera appear to have diversified during the middle Eocene and into the middle Miocene (ca. 44 - 11 mya, Figure 3) with recent rapid divergence of several of the genera, Barbibucca, Nemia, Nemopterella, Nemeura, Palmipenna and Sicyoptera/Semirhynchia, occurring during the late Miocene (ca. 4.5 mya), alluding to the fact that the diversification of the Nemopterinae appears to support both these hypotheses. The timing of the recent diversification events seems to follow the recent speciation of the Ruschioideae, indicating that an adaptive shift of the nemopterines may have occurred in response to the Ruschioideae distribution shifts linked to climatic oscillations. Further empirical evidence however is needed to test whether this is an adaptive radiation. Present observations, noted on radially symmetrical flowers, of adult nemopterine pollen feeding include the plant families Aizoaceae, Asteraceae and Molluginaceae (Ball pers. obs.). Feeding behaviour of Nemoptera sinuata Olivier in the Balkan-Anatolian peninsular was noted on flowers from the families Asteraceae and Brassicaceae (Krenn et al., 2008). It is therefore possible that the initial diversification of Nemopterinae was influenced by the radiation of the ruschoids, and that they subsequently adapted to feeding on other plant species as well. This is a hypothesis that will be tested in subsequent studies on pollen composition in the alimentary canals of preserved and freshly-collected specimens, as well as field observations. The greatest extant concentration of nemopterines is in the more arid portions of the Western and Northern Cape Provinces, where a variety of families of ephemeral spring flowers are visited by a large number of different orders of insects. Present local observations (Ball pers. obs.) confirm that the community patterns of plant-pollinator interactions reveal that angiosperm 
species are typically visited by many taxa of potential pollinators and that the majority of flower visitors are noted on multiple plant species (Geber and Moeller, 2006; Waser and Ollerton, 2006).

Apart from the radiation in South Africa, there has also been a similar, albeit smaller, radiation of a single genus, Chasmoptera in Western Australia where three species occur. In the southern Palaearctic there has been a radiation of two genera, Nemoptera Latrielle and Lertha. Both of these areas share a Mediterranean climate similar to that of the Western Cape Province of South Africa. The South African genus, Sicyoptera, most closely resembles Chasmoptera and Lertha and is restricted to the fynbos component in the south western part of the Western Cape Province, whereas most of the recent radiation of genera has taken place along the central and northern parts of the west coast area, where the largest simultaneous radiation of Ruschioideae has also taken place (Klak et al., 2004).

\section{Acknowledgements}

The authors would like to thank Tony Brinkman and Andre Marais for their patience, time and passion in collecting samples of this enigmatic group without which this study would not have been possible. CS is indebted to Isa-Rita Russo for all her hard work in the lab. Christian Deschodt is thanked for his help with drawing the map. Funding for the genetic analysis was provided through the National Research Foundation (NRF) with additional private funding from J.B. Ball.

\section{References}

Bolus, H., 1886. Sketch of the flora of South Africa. Richards and Sons, Cape Town.

Carpenter, F.M., 1959. Fossil Nemopteridae (Neuroptera). Psyche 66, 20-24.

Castresana, J., 2000. Selection of conserved blocks from multiple alignments for their use in phylogenetic analysis. Mol. Biol. Evol. 17, 540-552.

Cognato, A.I., Vogler, A.P., 2001. Exploring data interaction and nucleotide alignment in a multiple gene analysis of Ips (Coleoptera: Scolytinae). Syst. Biol. 50, 758-780.

deMenocal, P.B., 1995. Plio-pleistocene African climate. Science 270, 53-59.

deMenocal, P.B., 2004. African climate change and faunal evolution during the pliocene-pleistocene. Earth Planet. Sc. Lett. 220, 3-24. 
Drummond, A., Rambaut, A., 2007. BEAST: Bayesian evolutionary analysis by sampling trees. BMC Evol. Biol. 7, 214.

Felsenstein, J., 1985. Confidence limits on phylogenies: an approach using the bootstrap. Evol. 39, 783791.

Galley, C., Bytebier, B., Bellstedt, D.U., Linder, P., 2007. The Cape element in the afrotemperate flora: from Cape to Cairo? Proc. R. Soc. Lond. B. 274, 535-543.

Galley, C., Linder, H.P., 2006. Geographical affinities of the Cape flora, South Africa. J. Biogeogr. 33, 236-250.

Geber, M.A., Moeller, D.A., 2006. Pollinator responses to plant communities and implications for reproductive character evolution. In: Harder, L.D., Barrett, S.C.H. (Eds.), Ecology and Evolution of Flowers. Oxford University Press, Oxford, pp. 102-119.

Gillespie, J.J., Munro, J.B., Heraty, J.M., Yoder, M.J., Owen, A.K., Carmichael, A.E., 2005. A secondary structural model of the 28S rRNA expansion segments D2 and D3 for chalcidoid Wasps (Hymenoptera: Chalcidoidea). Mol. Biol. Evol. 22, 1593-1608.

Goldblatt, P., Manning, J.C., 2002. Plant diversity of the Cape region of southern Africa. Ann. MO. Bot. Gard. 89, 281-302.

Grimaldi, D., Engel, M.S., 2005. Evolution of Insects. Cambridge University Press, New York. Haring, E., Aspöck, U., 2004. Phylogeny of the Neuroptera: a first molecular approach. Syst. Entomol. 29, 415-430.

Huelsenbeck, J.P., Ronquist, F., 2001. MRBAYES: Bayesian inference of phylogenetic trees. Bioinforma. 17, 754-755.

Klak, C., Reeves, G., Hedderson, T., 2004. Unmatched tempo of evolution in Southern African semidesert ice plants. Nature 427, 63-65.

Krenn, H.W., Gereben-Krenn, B.A., Steinwender, B.M., Popov, A., 2008. Flower visiting Neuroptera: mouthparts and feeding behaviour of Nemoptera sinuata (Nemopteridae). Eur. J. Entomol. 105, 267-277. 
Leon, B., Picker, M.D., 1990a. Behavioral thermoregulation in Palmipenna aeoleoptera (Neuroptera) - do the hypertrophied hindwings play a role? J. Insect Behav. 3, 381-390.

Leon, B., Picker, M.D., 1990b. Function of the hindwings of Palmipenna aeoleoptera Picker (Insecta: Neuroptera: Nemopteridae). In: Mansell, M.W., Aspöck, H. (Eds.), Advances in Neuropterology. Proceedings of the Third International Symposium on Neuropterology. South African Department of Agricultural Development, Pretoria, Berg en Dal, Kruger National Park, South Africa, pp. 89-94.

Linder, H.P., 2003. The radiation of the Cape flora, southern Africa. Biol. Rev. 78, 597-638.

Linder, H.P., 2005. Evolution of diversity: the Cape flora. Trends Plant Sci. 10, 536-541.

Löytynoja, A., Goldman, N., 2005. An algorithm for progressive multiple alignment of sequences with insertions. Proc. Natl. Acad. Sci. USA 102, 10557-10562.

Löytynoja, A., Goldman, N., 2008. Phylogeny-aware gap placement prevents errors in sequence alignment and evolutionary analysis. Science 320, 1632-1635.

Maddison, D., Maddison, W., 1992. MacClade: Analysis of phylogeny and character evolution. Sinauer Associates Sunderland, MA.

Mansell, M.W., 1973. The first record of a larval nemopterid from southern Africa (Neuroptera: Nemopteridae: Nemopterinae). J. Entomol. Soc. S. Afr. 36, 133-137.

Mansell, M.W., 1976. The larva of Laurhervasia setacea (Klug), (Neuroptera: Nemopteridae: Crocinae) from southern Africa. J. Entomol. Soc. S. Afr. 39, 153-158.

Mansell, M.W., 1977. A new genus and species in the Crocinae (Neuroptera: Nemopteridae) from southern Africa. J. Entomol. Soc. S. Afr. 40, 195-203.

Mansell, M.W., 1980. The Crocinae of southern Africa (Neuroptera: Nemopteridae). 1. The genera Laurhervasia Navás and Thysanocroce Withycombe. J. Entomol. Soc. S. Afr. 43, 341-365.

Mansell, M.W., 1981a. The Crocinae of southern Africa (Neuroptera: Nemopteridae). 2. The genus Concroce Tjeder. J. Entomol. Soc. S. Afr. 44, 91-106. 
Mansell, M.W., 1981b. The Crocinae of southern Africa (Neuroptera: Nemopteridae). 3. The genus

Tjederia Mansell, with keys to the southern African Crocinae. J. Entomol. Soc. S. Afr. 44, 245-257.

Mansell, M.W., 1986. Biogeography and phylogeny of the Crocinae (Neuroptera: Nemopteridae). In:

Gepp, J., Aspöck, H., Hölzel, H. (Eds.), Recent Research in Neuropterology, Graz Austria, pp. 77-85.

Mansell, M.W., 1996. Unique morphological and biological attributes: the keys to success in Nemopteridae (Insecta: Neuroptera). In: Canard, M., Aspöck, H., Mansell, M.W. (Eds.), Pure and Applied Research in Neuropterology. Proceedings of the Fifth International Symposium on Neuropterology, Cairo, Egypt, pp. 171-180.

Mucina, L., Rutherford, M.C., 2006. The vegetation of South Africa, Lesotho and Swaziland. South African National Biodiversity Institute, Pretoria.

Nylander, J.A.A., 2004. MrModeltest v2. Program distributed by the author. Evolutionary Biology Centre, Uppsala University.

Picker, M.D., 1984. A new genus and species of spoon-wing lacewing (Neuroptera: Nemopteridae) from Namaqualand, South Africa. J. Entomol. Soc. S. Afr. 47, 259-268.

Picker, M.D., 1987. An unusual species of spoon-wing lacewing (Neuroptera: Nemopteridae) from South Africa, with notes on its biology. Syst. Entomol. 12, 239-248.

Picker, M.D., Leon, B., 1990. Population biology of Palmipenna aeoleoptera Picker with reference to the possible semaphore function of the hindwings (Insecta: Neuroptera: Nemopteridae). In: Mansell, M.W., Aspöck, H. (Eds.), Advances in Neuropterology. Proceedings of the Third International Symposium on Neuropterology. South African Department of Agricultural Development, Pretoria, Berg en Dal, Kruger National Park, pp. 95-99.

Picker, M.D., Leon, B., Londt, J.G.H., 1991. The hypertrophied hindwings of Palmipenna aeoleoptera Picker, 1987 (Neuroptera, Nemopteridae) reduce attack by robber flies by increasing apparent body size. Anim. Behav. 42, 821-825.

Picker, M.D., Leon, B., Londt, J.G.H., 1992. Influence of hindwing size in nemopterids (Insecta: Neuroptera: Nemopteridae) on predation by robber flies (Diptera: Asilidae). In: Canard, M., Aspöck, H., Mansell, M.W. (Eds.), Current Research in Neuropterology. Proceedings of the Fourth International 
Symposium on Neuropterology. Privately printed, Toulouse, France, Bagnères-de-Luchon, France, pp. 313-318.

Potts, R., 1998. Environmental hypotheses of Hominin evolution. Yearb. Phys. Anthr. 41, 93-136.

Price, B.W., Barker, N.P., Villet, M.H., 2007. Patterns and processes underlying evolutionary significant unts in the Platypleura stridula L. species complex (Hemiptera: Cicadidae) in the Cape Floristic region, South Africa. Mol. Ecol. 16, 2574-2588.

Roux, P., 1833. Lettre relative à divers Coquilles, Crustacés, Insectes, Reptiles et Oiseaux, observés en Égypte; adressée par M. Roux à M. le baron de Férussac. Ann. Sci. Nat. Zoologie 28, 72-78.

Schulze, E.-D., Beck, E., Müller-Holstein, K., 2005. Plant Ecology. Springer Berlin, Heidelberg.

Simon, C., Frati, F., Benckenbach, A., Crespi, B., Liu, H., Flook, P., 1994. Evolution, weighting, and phylogenetic utility of mitochondrial gene sequences and a compilation of conserved polymerase chain reaction primers. Ann. Entomol. Soc. Am. 87, 652-701.

Swofford, D.L., 2003. PAUP*: Phylogenetic Analysis Using Parsimony (* and Other Methods). Sinauer Associates, Sunderland, MA.

Tjeder, B., 1967. Neuroptera-Planipennia. The lace-wings of southern Africa. 6. Family Nemopteridae. In: Hanström, B., Brinck, P., Rudebec, G. (Eds.), South African Animal Life. Swedish Natural Science Research Council., Stockholm., pp. 290-501.

Tolley, K.A., Burger, M., Turner, A.A., Matthee, C.A., 2006. Biogeographic patterns and phylogeography of dwarf chameleons (Bradypodion) in an African biodiversity hotspot. Mol. Ecol. 15, 781-793.

van Zinderen Bakker, E.M., 1975. The origin and palaeoenvironment of the Namib Desert Biome. J. Biogeogr. 2, 65-73.

Walker, M.H., Picker, M.D., Leon, B., 1994. Eversible abdominal vesicles and some observations of the male reproductive system of the spoon-wing lacewing Palmipenna (Neuroptera, Nemopteridae). J. Morphol. 219, 47-58.

Ward, J.D., Seely, M.K., Lancaster, N., 1983. On the antiquity of the Namib. S. Afr. J. Sci. 79, 175-183. 
Waser, N.M., Ollerton, J., 2006. Plant-pollinator interactions: From specialization to generalization. University of Chicago Press, Chicago.

Winterton, S.L., Hardy, N.B., Wiegmann, B.M., 2010. On wings of lace: phylogeny and bayesian divergence time estimates of Neuropterida (Insecta) based on morphological and molecular data. Syst. Entomol. 35, 349-378. 
Figure 1. Map indicating the genera and species localities of the Nemopterinae. 




Figure 2. Bayesian phylogram of combined dataset analysis (COI, 16S, 18S and 28S domain 2). Posterior probabilities, parsimony and ML bootstrap are given, respectively. Dashes (-) on nodes indicate weak/no support. 


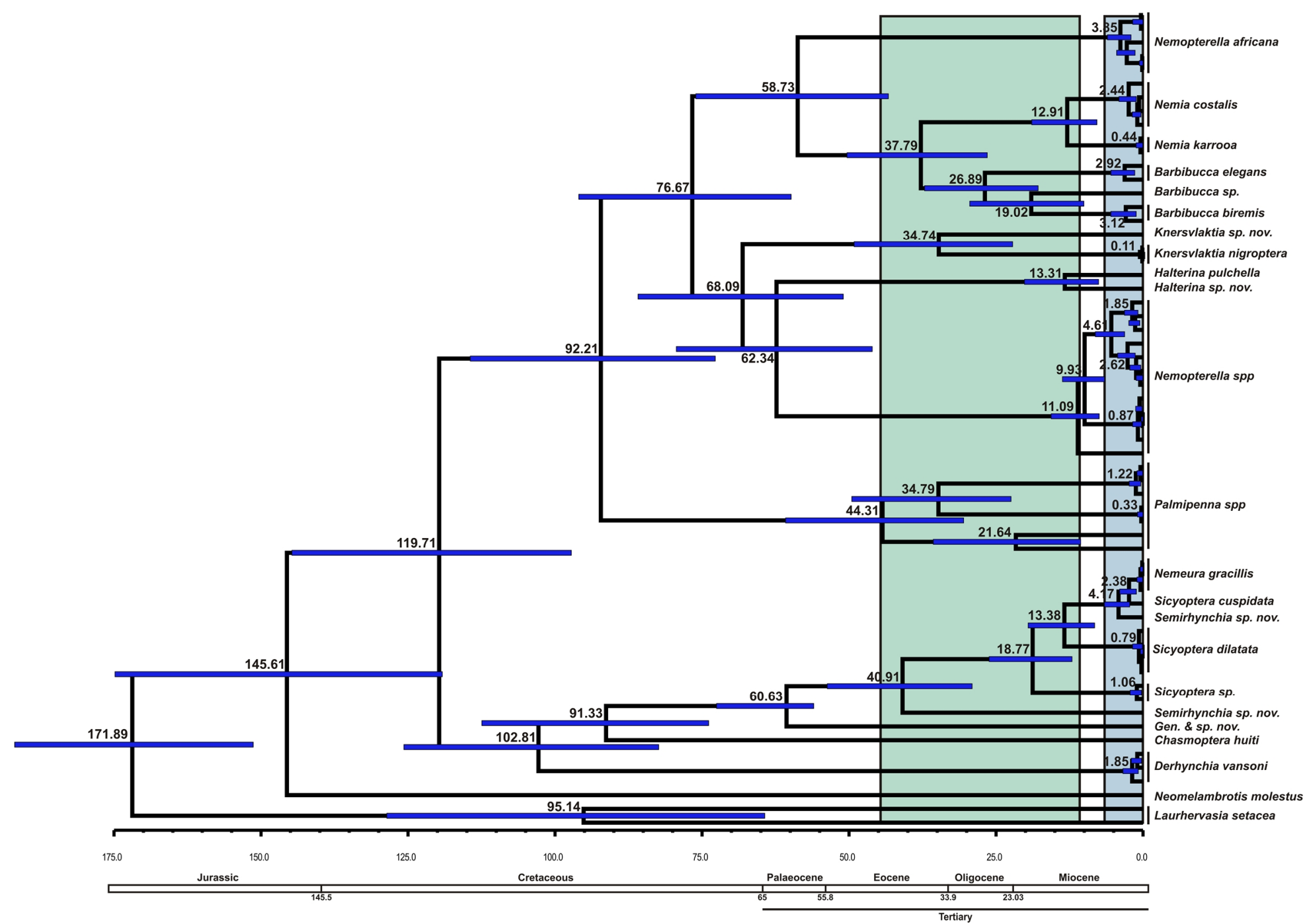

Figure 3. Estimated times of divergence for the major lineages of the Nemopterinae. Nodes on the phylogram represent means of the probability distributions for node ages. The time intervals for the $95 \%$ probability of actual age are represented as blue bars. Green box represents the time period of slow accumulation of genera, blue box represents recent diversification. 
Table 1. Sampled species for this study along with their collection locality. X - indicates amplification failed i.e. no sequence data available, Comb. indicates the samples used in the combined analysis

\begin{tabular}{|c|c|c|c|c|c|c|c|}
\hline Taxon & Locality & Specimen ID & COI & $16 S$ & $28 S$ domain 2 & $18 S$ & Comb. \\
\hline Barbibucca biremis & Graafwater & BBGW01 & $\sqrt{ }$ & $\sqrt{ }$ & $\sqrt{ }$ & $\sqrt{ }$ & $\sqrt{ }$ \\
\hline \multirow[t]{2}{*}{ Barbibucca elegans } & Klompbome, Loeriesfontein & BEL01 & $\sqrt{ }$ & $\sqrt{ }$ & $\mathbf{x}$ & $\mathbf{x}$ & $\sqrt{ }$ \\
\hline & Klompbome, Loeriesfontein & BEL02 & $\sqrt{ }$ & $\sqrt{ }$ & $\sqrt{ }$ & $\sqrt{ }$ & $\sqrt{ }$ \\
\hline Barbibucca sp. & Wallekraal & BWK01 & $\sqrt{ }$ & $\sqrt{ }$ & $\sqrt{ }$ & $\sqrt{ }$ & $\sqrt{ }$ \\
\hline Barbibucca sp. & Knersvlakte & BKP01 & $\mathbf{x}$ & $\sqrt{ }$ & $\sqrt{ }$ & $\sqrt{ }$ & $\sqrt{ }$ \\
\hline Chasmoptera huitti & Coorow, Western Australia & CS01 & $\sqrt{ }$ & $\sqrt{ }$ & $\sqrt{ }$ & $\sqrt{ }$ & $\sqrt{ }$ \\
\hline \multirow[t]{3}{*}{ Derhynchia vansoni } & Tswalu - Gosa Dunes & DVT01 & $\sqrt{ }$ & $\sqrt{ }$ & $\sqrt{ }$ & $\sqrt{ }$ & $\sqrt{ }$ \\
\hline & Tswalu - Gosa Dunes & DVT02 & $\sqrt{ }$ & $\sqrt{ }$ & $\sqrt{ }$ & $\sqrt{ }$ & $\sqrt{ }$ \\
\hline & Tswalu - Gosa Dunes & DVT03 & $\sqrt{ }$ & $\sqrt{ }$ & $\sqrt{ }$ & $\sqrt{ }$ & $\sqrt{ }$ \\
\hline Halterina sp. nov. & Zandrug $10 \mathrm{~km}$ north Clanwilliam & HBCZO3 & $\sqrt{ }$ & $\sqrt{ }$ & $\sqrt{ }$ & $\sqrt{ }$ & $\sqrt{ }$ \\
\hline Halterina pulchella & Koeberg & НРСТ01 & $\sqrt{ }$ & $\sqrt{ }$ & $\sqrt{ }$ & $\sqrt{ }$ & $\sqrt{ }$ \\
\hline \multirow[t]{2}{*}{ Knersvlaktia nigroptera } & Knersvlakte & KNK01 & $\sqrt{ }$ & $\sqrt{ }$ & $\sqrt{ }$ & $\sqrt{ }$ & $\sqrt{ }$ \\
\hline & Knersvlakte & KNK02 & $\sqrt{ }$ & $\sqrt{ }$ & $\sqrt{ }$ & $x$ & $\sqrt{ }$ \\
\hline Knersvlaktia sp. nov. & Vyftienmylberg & BVB01 & $\sqrt{ }$ & $\sqrt{ }$ & $\mathbf{x}$ & $\sqrt{ }$ & $\sqrt{ }$ \\
\hline \multirow[t]{3}{*}{ Nemia costalis } & Clanwilliam & NCCD02 & $\sqrt{ }$ & $\sqrt{ }$ & $\sqrt{ }$ & $\sqrt{ }$ & $\sqrt{ }$ \\
\hline & Clanwilliam & NCCD03 & $\sqrt{ }$ & $\sqrt{ }$ & $\sqrt{ }$ & $\sqrt{ }$ & $\sqrt{ }$ \\
\hline & Clanwilliam & NCCD04 & $\sqrt{ }$ & $\sqrt{ }$ & $\sqrt{ }$ & $\sqrt{ }$ & $\sqrt{ }$ \\
\hline \multirow[t]{2}{*}{ Nemia karrooa } & Marydale, Swartkopspan & NAMD01 & $\sqrt{ }$ & $\sqrt{ }$ & $\sqrt{ }$ & $\sqrt{ }$ & $\sqrt{ }$ \\
\hline & Marydale, Swartkopspan & NAMD02 & $\sqrt{ }$ & $\sqrt{ }$ & $\sqrt{ }$ & $\sqrt{ }$ & $\sqrt{ }$ \\
\hline
\end{tabular}




\begin{tabular}{|c|c|c|c|c|c|c|c|}
\hline Taxon & Locality & Specimen ID & COI & $16 S$ & $28 \mathrm{~S}$ domain 2 & $18 \mathrm{~S}$ & Comb. \\
\hline \multirow[t]{5}{*}{ Nemopterella africana } & Doornfontein & NKDTK01 & $\sqrt{ }$ & $\sqrt{ }$ & $\sqrt{ }$ & $\sqrt{ }$ & $\sqrt{ }$ \\
\hline & Doornfontein & NKDTK03 & $\sqrt{ }$ & $\sqrt{ }$ & $\mathbf{x}$ & $\sqrt{ }$ & $\sqrt{ }$ \\
\hline & Doornfontein & NKDTK04 & $\sqrt{ }$ & $\sqrt{ }$ & $\sqrt{ }$ & $\sqrt{ }$ & $\sqrt{ }$ \\
\hline & Uitkyk, Piketberg & NAC02 & $\sqrt{ }$ & $\sqrt{ }$ & $\sqrt{ }$ & $\sqrt{ }$ & $\sqrt{ }$ \\
\hline & Uitkyk, Piketberg & NAC03 & $\sqrt{ }$ & $\sqrt{ }$ & $\sqrt{ }$ & $\sqrt{ }$ & $\sqrt{ }$ \\
\hline \multirow[t]{2}{*}{ Nemopterella longicornis } & Sterkfontein & NLTS01 & $\sqrt{ }$ & $\sqrt{ }$ & $\sqrt{ }$ & $\sqrt{ }$ & $\sqrt{ }$ \\
\hline & Sterkfontein & NLTS02 & $\sqrt{ }$ & $\sqrt{ }$ & $\sqrt{ }$ & $\sqrt{ }$ & $\sqrt{ }$ \\
\hline \multirow[t]{3}{*}{ Nemopterella munroi } & Vioolsdrif & NMSK01 & $\sqrt{ }$ & $\sqrt{ }$ & $\sqrt{ }$ & $\sqrt{ }$ & $\sqrt{ }$ \\
\hline & Vioolsdrif & NMSK02 & $\sqrt{ }$ & $\sqrt{ }$ & $\sqrt{ }$ & $\sqrt{ }$ & $\sqrt{ }$ \\
\hline & Vioolsdrif & NMSK03 & $\sqrt{ }$ & $\sqrt{ }$ & $\sqrt{ }$ & $\sqrt{ }$ & $\sqrt{ }$ \\
\hline \multirow[t]{3}{*}{ Nemopterella papio } & Vioolsdrif & NPSK01 & $\sqrt{ }$ & $\sqrt{ }$ & $\sqrt{ }$ & $\sqrt{ }$ & $\sqrt{ }$ \\
\hline & Vioolsdrif & NPSK03 & $\sqrt{ }$ & $\sqrt{ }$ & $\sqrt{ }$ & $\sqrt{ }$ & $\sqrt{ }$ \\
\hline & Vioolsdrif & NPSK05 & $\sqrt{ }$ & $\sqrt{ }$ & $\mathbf{x}$ & $\sqrt{ }$ & $\sqrt{ }$ \\
\hline Nemopterella papio & Vioolsdrif & NPVD01 & $\sqrt{ }$ & $\sqrt{ }$ & $\sqrt{ }$ & $\sqrt{ }$ & $\sqrt{ }$ \\
\hline Nemopterella peringueyi & Beaufort West & NBW01 & $\sqrt{ }$ & $\sqrt{ }$ & $\sqrt{ }$ & $\sqrt{ }$ & $\sqrt{ }$ \\
\hline \multirow[t]{2}{*}{ Nemopterella sp. } & Tswalu Reserve & NSS01 & $\sqrt{ }$ & $\sqrt{ }$ & $\sqrt{ }$ & $\sqrt{ }$ & $\sqrt{ }$ \\
\hline & Tswalu Reserve & NSS02 & $\sqrt{ }$ & $\sqrt{ }$ & $\sqrt{ }$ & $\sqrt{ }$ & $\sqrt{ }$ \\
\hline \multirow[t]{3}{*}{ Nemeura gracilis } & Worcester & NGW01 & $\sqrt{ }$ & $\sqrt{ }$ & $\sqrt{ }$ & $\sqrt{ }$ & $\sqrt{ }$ \\
\hline & Worcester & NGW02 & $\sqrt{ }$ & $\sqrt{ }$ & $\sqrt{ }$ & $\sqrt{ }$ & $\sqrt{ }$ \\
\hline & Worcester & NGW03 & $\sqrt{ }$ & $\sqrt{ }$ & $\sqrt{ }$ & $\sqrt{ }$ & $\sqrt{ }$ \\
\hline \multirow[t]{3}{*}{ Palmipenna aeoleoptera } & Biedou' Clanwilliam & PAC02 & $\sqrt{ }$ & $\sqrt{ }$ & $\sqrt{ }$ & $\sqrt{ }$ & $\sqrt{ }$ \\
\hline & Biedou' Clanwilliam & PAC03 & $\sqrt{ }$ & $\sqrt{ }$ & $\sqrt{ }$ & $\sqrt{ }$ & $\sqrt{ }$ \\
\hline & Biedou' Clanwilliam & PAC10 & $\sqrt{ }$ & $\sqrt{ }$ & $\sqrt{ }$ & $\sqrt{ }$ & $\sqrt{ }$ \\
\hline
\end{tabular}




\begin{tabular}{|c|c|c|c|c|c|c|c|}
\hline Taxon & Locality & Specimen ID & $\mathrm{COI}$ & $16 S$ & 28S domain 2 & $18 S$ & Comb. \\
\hline \multirow[t]{2}{*}{ Palmipenna palmulata } & Brandkop & PBK01 & $\sqrt{ }$ & $\sqrt{ }$ & $\sqrt{ }$ & $\sqrt{ }$ & $\sqrt{ }$ \\
\hline & Kobee Pass & PPKP02 & $\sqrt{ }$ & $\sqrt{ }$ & $x$ & $\sqrt{ }$ & $\sqrt{ }$ \\
\hline \multirow[t]{2}{*}{ Palmipenna pilicornis } & Biedou' Clanwilliam & PPB02 & $\sqrt{ }$ & $\sqrt{ }$ & $\mathbf{x}$ & $\sqrt{ }$ & $\sqrt{ }$ \\
\hline & Biedou' Clanwilliam & PPB03 & $\sqrt{ }$ & $\sqrt{ }$ & $\mathbf{X}$ & $\sqrt{ }$ & $\sqrt{ }$ \\
\hline Semirhynchia sp. nov. & Clanwilliam & SMC02 & $\sqrt{ }$ & $\sqrt{ }$ & $\mathbf{X}$ & $\sqrt{ }$ & $\sqrt{ }$ \\
\hline Semirhynchia sp. nov. & Vanrhynsdorp - Kobee Pass & SV01 & $\sqrt{ }$ & $\sqrt{ }$ & $\sqrt{ }$ & $\sqrt{ }$ & $\sqrt{ }$ \\
\hline Sicyoptera cuspidata & Worcester & SCBB01 & $\sqrt{ }$ & $\sqrt{ }$ & $\sqrt{ }$ & $\sqrt{ }$ & $\sqrt{ }$ \\
\hline \multirow[t]{4}{*}{ Sicyoptera dilatata } & Galgeberg & SDGG01 & $\sqrt{ }$ & $\sqrt{ }$ & $\mathbf{x}$ & $\sqrt{ }$ & $\sqrt{ }$ \\
\hline & Galgeberg & SDGG02 & $\sqrt{ }$ & $\sqrt{ }$ & $\sqrt{ }$ & $\sqrt{ }$ & $\sqrt{ }$ \\
\hline & Galgeberg & SDGG03 & $\mathbf{x}$ & $\sqrt{ }$ & $\sqrt{ }$ & $\sqrt{ }$ & $\sqrt{ }$ \\
\hline & Galgeberg & SDGB01 & $\sqrt{ }$ & $\sqrt{ }$ & $\sqrt{ }$ & $\sqrt{ }$ & $\sqrt{ }$ \\
\hline \multirow[t]{2}{*}{ Sicyoptera sp. nov. } & Welbedacht & SWB01 & $\sqrt{ }$ & $\sqrt{ }$ & $\sqrt{ }$ & $\mathbf{X}$ & $\sqrt{ }$ \\
\hline & & SWB02 & $\sqrt{ }$ & $\sqrt{ }$ & $\sqrt{ }$ & $\mathbf{x}$ & $\sqrt{ }$ \\
\hline Gen. \& sp. nov. & Kamieskroon & SSKK01 & $\sqrt{ }$ & $\sqrt{ }$ & $\sqrt{ }$ & $\sqrt{ }$ & $\sqrt{ }$ \\
\hline \multicolumn{8}{|l|}{ Out-groups } \\
\hline Ascalaphidae (Neomelambrotus molestus) & Klipvlei Farm & MA01 & $\sqrt{ }$ & $\sqrt{ }$ & $\sqrt{ }$ & $\sqrt{ }$ & $\sqrt{ }$ \\
\hline Crocinae (Laurhervasia setacea) & Kelkiewyn Farm & LSKF01 & $\sqrt{ }$ & $\sqrt{ }$ & $\sqrt{ }$ & $\mathbf{X}$ & $\sqrt{ }$ \\
\hline Crocinae (Laurhervasia setacea) & Piketberg 'Uitkyk' & СРC01 & $\sqrt{ }$ & $\sqrt{ }$ & $\sqrt{ }$ & $\mathbf{x}$ & $\sqrt{ }$ \\
\hline
\end{tabular}


Table 2. Summary of oligonucleotide primers used in this study

\begin{tabular}{llll}
\hline Locus (length) & Primer name and sequence & Length & Reference \\
\hline Cytochrome oxidase I & C1-J-2183 (5'CAACATTTATTTTGATTTTTTGG 3') & 23mer & Simon et al., (1994) \\
& TL2-N-3014 (TCCAATGCACTAATCTGCCATATTA 3') & 25mer & Simon et al., (1994) \\
16S rRNA & LR-J-12961 (5' TTTAATCCAACATCGAGG 3') & $18 \mathrm{mer}$ & Cognato and Vogler (2001) \\
& LRN-N-13398 (5' CGCCTGTTTAACAAAAACAT 3') & $20 \mathrm{mer}$ & Simon et al.., (1994) \\
\multirow{2}{*}{ 28S rRNA domain 2 } & D2-3551 (5' CGTGTTGCTTGATAGTGCAGC 3') & $21 \mathrm{mer}$ & Gillespie [et al., (2005) \\
& D2-4057 (5' TCAAGACGGGTCCTGAAAGT 3') & 20mer & Gillespie et al., (2005) \\
18S rRNA & 18S-intfw-STI2 (5' ATCAAGAACGAAAGTAGAG 3') & 20mer & Haring and Aspöck (2004) \\
& 18S-rev1 (5' ATGGGGACAATTGCAAGC 3') & 19mer & Haring and Aspöck (2004) \\
\hline
\end{tabular}

Table 3. Data characteristics and estimated model parameters for 16S, COI, 28S domain 2 and 18S datasets as applied to the MrBayes and *BEAST analyses ( $\mathrm{I}=$ proportion of invariable sites).

\begin{tabular}{ccccc}
\hline & $\mathbf{1 6 S}$ & COI & D2 & 18S \\
\hline Best-fit model & $\mathrm{GTR}+\mathrm{I}+\mathrm{G}$ & $\mathrm{HKY}+\mathrm{I}+\mathrm{G}$ & $\mathrm{GTR}+\mathrm{I}+\mathrm{G}$ & $\mathrm{GTR}+\mathrm{I}+\mathrm{G}$ \\
A frequency & 0.405 & 0.374 & 0.336 & 0.255 \\
C frequency & 0.154 & 0.152 & 0.123 & 0.199 \\
G frequency & 0.084 & 0.068 & 0.167 & 0.242 \\
T frequency & 0.358 & 0.406 & 0.373 & 0.305 \\
Gamma & 1.529 & 0.381 & 0.675 & 0.454 \\
$\mathrm{I}$ & 0.579 & 0.467 & 0. & 0.581 \\
\hline
\end{tabular}

